\title{
CHD1 wt Allele
}

National Cancer Institute

\section{Source}

National Cancer Institute. CHD1 wt Allele. NCI Thesaurus. Code C107120.

Human CHD1 wild-type allele is located within 5q15-q21 and is approximately $71 \mathrm{~kb}$ in length. This allele, which encodes chromodomain-helicase-DNA-binding protein 1, plays a role in the regulation of transcription by the modification of chromatin structure. 